\title{
Quando a geo-história avança sobre os significados de um espaço urbano: as paisagens culturais e as transformaçóes identitárias da fronteira Brasil-Argentina
}

\begin{abstract}
Muriel Pinto. Universidade Federal do Pampa, São Borja, Brasil. Rodrigo Maurer. Universidade Federal do Pampa, Bagé, Brasil.
\end{abstract}

RESUmo | Em recentes estudos visando a elaboração do Projeto piloto "Itinerário cultural da Região das Missóes Jesuítico-Guarani” foram discutidos conceitos e estratégias para as novas categorias de bens culturais que vem sendo proposta pela UNESCO. Entre as mais novas categorias incluem-se as paisagens culturais e itinerários culturais. A área em estudo, a cidade missioneira de São Borja-Brasil, destaca-se na regiáo por possuir uma diversidade de bens culturais que representam momentos históricos relevantes no cenário brasileiro. Recursos culturais que expressam sentidos e significados aos espaços sociais através das paisagens. O principal objetivo do estudo está em analisar a cidade como um espaço territorial de produção, intervenção e trocas culturais, voltado para a análise da construção das identidades e suas influências nas transformaçôes dos territórios urbanos. Para tanto, utilizaram-se as paisagens culturais como instrumento de pesquisa. Como principal resultado pode-se salientar a realização de uma interpretação crítica para os espaços-temporais urbanos.

PALAVRAS-CHAVE: história das cidades, patrimônio, cultura urbana.

ABSTRACT | In recent studies aimed at developing the pilot project "Cultural Itinerary of the Region of the Jesuit-Guarani Missions", concepts and strategies for new categories of cultural property proposed by UNESCO were discussed. Among the newer categories, those of cultural landscapes and cultural routes were included. The area under study - the missionary town of San Borja, Brazil - stands out in the region as having a diversity of cultural goods that represent important historical moments in the Brazilian scene and express their meanings across landscapes. The main objective of the study is to examine the city as a territorial space of production, intervention, and cultural exchanges, focusing on the analysis of the construction of identities and their influence in the transformation of urban territories. For this purpose, we used cultural landscapes as a research tool, leading to a critical interpretation to the urban spatio-temporal scenery.

KEY WORDS: history of cities, heritage, urban culture.

Recibido el 10 de abril de 2012, aprobado el 28 de diciembre de 2012

E-Mail: Muriel Pinto, murielpinto@yahoo.com.br | Rodrigo Maurer, rodrigomaurer@hotmail.com 


\section{Consideraçóes iniciais...}

O recorte em estudo, a cidade de São Borja, é um município que faz parte do Estado do Rio Grande do Sul, Brasil. O devido município está localizado às margens do rio Uruguai, fazendo fronteira com a municipalidade argentina de Santo Tomé. Em relação à sua regionalização, São Borja faz parte da mesorregião Sudoeste RioGrandense, conhecida como campanha ou pampa gaúcho. Está também inserida na chamada região histórica das Missóes Jesuítico Guarani. A fundação de São Borja (1690) foi realizada pela migração de índios guaranis da antiga redução jesuítica de Santo Tome, acrescida de índios do pampa (ver Figura 1).

A construção territorial da área em estudo, está relacionada a conflitos militares e pelas disputas territoriais entre as Coroas espanhola e portuguesa. As características geográficas fazem de São Borja um ponto de referência tanto histórico como geopolítico. O mesmo teve início no período colonial e se estendeu até o século XIX, ao sofrer com as ofensivas militares da Guerra do Paraguai, e mais recentemente, destaca-se como "corredor" de comércio exterior no Mercosul. O local ainda é cidade natal dos ex-presidentes brasileiros, Getúlio Vargas e João Goulart.

Os eventos históricos transformaram as identidades e materializaram o patrimônio histórico e cultural local, o que contribuiu para a criaçáo de uma quantidade expressiva de bens patrimoniais que estáo espacialmente distribuídos na área urbana do município. Sendo assim, a cidade em estudo apresenta características urbanas que misturam representaçóes socioculturais espanholas e portuguesas.

\section{FIgURA 1 | Localização de São Borja na regiáo das Missões Jesuítico Guarani}

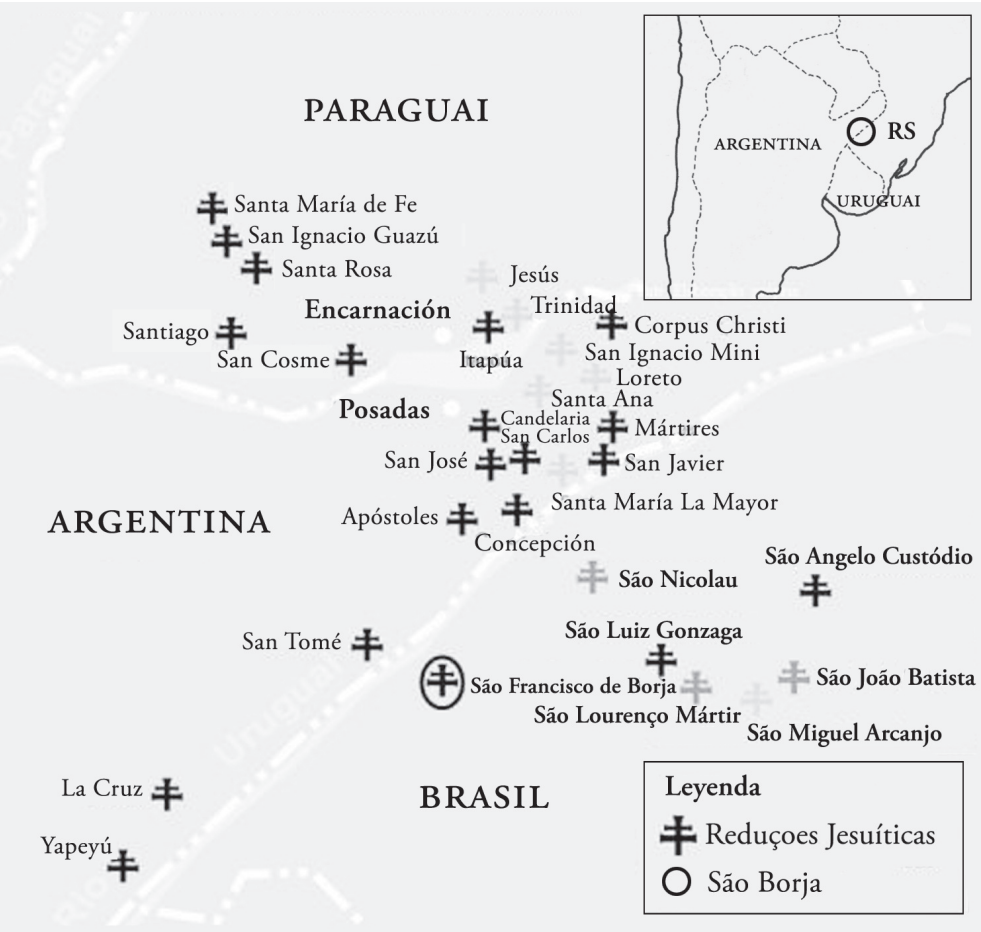

FONTE PROJETO ITINERÁRIOS CULTURAIS DO MERCOSUL, ADAPTADO POR MURIEL PINTO 
A problemática da pesquisa procurou interrogar como as paisagens culturais geradas pelo patrimônio acabam por constituir as narrativas e açóes de pertencimento das identidades urbanas, questionando ainda, se os significados da cidade estáo relacionados aos processos geo-históricos ${ }^{1}$.

O município foi pensado na sua diversidade. As análises, portanto, referemse aos territórios de vida, que são constituídos por ideias, pelo cotidiano, pelas tradiçôes, costumes, símbolos, através de uma dialética do concreto com o abstrato.

Para tanto, o principal objetivo do estudo está em analisar a cidade como um espaço territorial de produção, intervenção e trocas culturais, voltado para a caracterização das transformaçóes do patrimônio histórico-cultural e da identidade, bem como o seu impacto sobre o território.

A metodologia ocupou-se de métodos de abordagens não experimentais. $\mathrm{O}$ estudo foi dividido em quatro etapas: interpretação histórica e geográfica da região; inventário do patrimônio e interpretação; levantamento e análise das representaçóes culturais; e análise das identidades. O tipo de pesquisa preponderante foi a qualitativa, que procurou realizar interpretaçóes de paisagens no espaço local, através da análise de discurso, estudo cartográfico, descriçóes, comparaçóes e pesquisa contextual/histórica.

No que cerne à etapa da interpretaçáo histórica e geográfica da região, foi utilizada a seguinte metodologia: análise do conteúdo, pesquisa bibliográfica/documental e entrevista oral. $\mathrm{O}$ conjunto levou em consideração situaçóes que compreendem o espaço humanizado da regiấo e a desnaturalização das identidades.

Muitas das informações históricas, principalmente as do período colonial, são oriundas de documentaçóes arroladas em arquivos da América Latina, dentre os quais, o Archivo General de la Nácion Argentina (agna Buenos Aires), Arquivo Histórico do Rio Grande do Sul (ahrgs, Porto Alegre), Centro da Cultura Missioneira (ссм, Santo Ângelo - Rio Grande do Sul), Arquivo Público de São Borja (APSB), entre outros.

A revisão bibliográfica possibilitou refletir os eventos históricos que abarcam tal localidade. Levou-se em consideração a preservação das manifestaçôes culturais que enaltecem características do meio urbano e dos espaços sociais partilhados pelos atuais mediadores culturais. A entrevista oral, contudo, promoveu uma interpretaçáo mais profunda do que concentra atualmente as práticas sociais dos lugares e possíveis difusóes culturais da cidade.

A etapa de inventário e interpretação do patrimônio de São Borja foi aplicada conforme à seguinte metodologia: questionários sobre os bens culturais; levantamento fotográfico; elaboração de cartografias; e pesquisa bibliográfica. Este momento foi o ponto alto da pesquisa, pois trouxe à tona questóes vinculadas aos elementos

1 A geo-história já teve uma importância significativa para o campo historiográfico quando a mesma era utilizada como base de investigação por alguns teóricos da escola dos Annales. Contudo, no estudo em destaque, tais reflexôes não serão aprofundadas, uma vez que utilizarse-á a expressão geo-história visando unicamente garantir as experiências que unificam não só as duas áreas de conhecimento, mas também as experiências individuais e acumulativas dos próprios pesquisadores. Portanto, o termo geo-história faz alusão ao arcabouço teórico e metodológico que concentra o objeto trabalhado. 
culturais, como por exemplo, o patrimônio arquitetônico, as festas, as manifestaçóes artísticas, instituiçóes culturais e o artesanato típico da localidade. Os resultados revelaram um entendimento consistente sobre a construçáo identitária regional. Muitas das informaçóes do inventário acabaram sendo utilizadas em mapas temáticos.

A terceira etapa buscou codificar dados referentes às representaçôes e às paisagens culturais geradas do patrimônio cultural e dos discursos sócio-regionais. Grande parte das informaçóes é oriunda de conteúdos musicais, projetos públicos, sites, que em um dado momento registraram os contextos culturais e cotidianos de São Borja (tanto eventos remotos quanto os atuais). Algumas informaçóes acabaram servindo de material de apoio em entrevistas com membros da comunidade em geral e em análises fotográficas (com fins de comparação entre os patrimônios materiais e imateriais do passado com situaçóes do presente). Os resultados trouxeram símbolos e elementos socioculturais que se mantiveram materializados no espaço. Uma análise sobre as paisagens culturais provaram as narrativas de construção das identidades missioneiras e seus respectivos processos de alteridades discursivas. Sendo assim, objetivou-se compreender os sentimentos de pertencimento das expressóes culturais dos territórios.

A análise das identidades de São Borja foi realizada conforme a interpretação conjunta das demais etapas do estudo. Portanto, a reflexáo sobre o patrimônio, representaçóes culturais, a análise histórica, e a pesquisa bibliográfica deram suporte para o pensamento das narrativas identitárias que concentram o espaço da fronteira em questão. Constatou-se ainda, que as relações de poder consolidam-se a partir destas identidades.

A importância da pesquisa justifica-se por apresentar uma temática cada vez mais rara nos estudos urbanos, que são as reflexóes geo-históricas. Estas procuraram a articulação entre o passado e o presente, integrando a complexidade e riqueza empírica da história e a compreensão geográfica das transformaçóes socioculturais das sociedades, que constróem paisagens e geram marcadores nos territórios urbanos.

\section{A importância estratégica da fundação da reduçáo de Sáo Francisco de Borja e suas decorrências históricas na regiáo missioneira}

As reduçóes jesuíticas estão entre os principais projetos socioculturais e patrimoniais que o "mundo católico" produziu durante a época moderna. No geral as narrativas visam valorizar a macro estrutura ou a expansão do projeto da Companhia de Jesus ${ }^{2}$. Contudo, uma moldura mais ampla depende de análises mais reduzidas, principalmente no que diz respeito aos cotidianos e possíveis desdobramentos sócios culturais de matizes diferenciadas, como as que envolveram as reduçóes indígenas. O desafio por hora compóe parte desse cenário investigativo, uma vez que, busca compreender as particularidades daquela que foi, para o período (séculos XVII e XVIII), uma redução de fronteira e, portanto, catalisadora de rotinas alternadas.

Por macroestrutura subentende-se a materialização das reduçóes principalmente no que diz respeito à parte arquitetônica das mesmas. 
Localizada na margem esquerda do rio Uruguai, a redução de São Borja preencheu um vazio condicional que separava as duas margens. Em várias oportunidades, a sua história confunde-se com a história de alguns grupos de índios pampeanos que costumavam transitar entre o espaço do pampa e os conjuntos reducionais da margem esquerda - Yapeyu, La Cruz e Santo Tomé - hoje território argentino (Jarque, 1687/2008). Os índios guenoas (também conhecidos como índios de Jesus María dos Guenoas), ilustram categoricamente os reflexos étnicos e culturais que concentraram a antiga redução borjista. A inclusão daqueles à redução acrescentou ao povo de São Borja adjetivos de índios inconstantes, saqueadores e indolentes. A passagem seguinte justifica o que acabamos de nos referir:

Este Pueblesíto de Jesus María nada se ha multíplícado, porque muchos dellos ya se han muerto, y los pocos otros se van paseando á ver á sus paríentes, llevando consigo algunos Guaranis de S. Borja consígo como ya amígos suyos, de suerte que el año de 21 estando yo este Pueblo de S. Borja Compañero del Pe Cura Joseph de Astorga ya no huvo de los Guanoas convertidos del Pueblo Jesus Maria pero los indíos Guaranís de S. Borja siempre con este título de Guanoàs convertidos, aunque no los huvo mas, han hecho varías pretencíones y suplícas à los Supers engañandolos varías vezes y enredandolos. Con esta sutrasa salíeron varías vezes con sus pretencíones y esto es el orígen y causa de tantos dísturbíos. Con este pretexto los Borjistas en varías partes se han espacídos, ocupando varíos pedasos de tíerras realengas en las vercinas Estancias, en dandoles convenía para robar ganado ageno (grifo do autor) ${ }^{3}$.

Tão importante quanto à descrição feita pelo religioso é o significado histórico que envolve a observação, pois reflete as dificuldades de convivência entre possíveis "diferentes" (índios reduzidos/guaranis e índios pampeanos/guenoas) num espaço potencialmente diversificado, como foram algumas reduçóes ${ }^{4}$. No entanto, o caso de São Borja é uma situação que foge do comum, pois se consiste na chamada identidade étnica, como bem demonstra a pesquisadora Maria Cristina dos Santos (1993):

la identidad étnica, no es una condición puramente subjetiva, sino el resultado de procesos históricos específicos que dotan al grupo de "un pasado común y de una serie de formas de relación y códigos de comunicación que sirven de fundamento, para la persistencia de una identidad étnica especifica", bien para la reconstrucción de la identidad (p. 37) (grifo do autor).

A fundação de São Borja, nesse caso, foi levada a cabo com a ambição de solucionar antigos anseios do projeto jesuítico na bacia do Prata, portanto, teve relaçáo direta com a regiáo escolhida. Dadas as proporçóes, a redução praticou a geopolítica de guarnição de fronteiras tão desejada na época pela coroa espanhola. Para Nogueira (2007, p.19), a partir da instalação "a Região Missioneira constitui-se em um espaço transfronteiriço integrado por territórios que pertencem hoje, à

3 Correspondência de Segismundo Asperger para o Governador de Buenos Aires, Francisco de Paula Bucareli y Úrsua. S. S. Apostolles, 10 de outubro de 1769. AGNA, Sala Ix: 18.05.01.

4 Vários estudiosos procuram, atualmente, compreender a problemática da diversidade étnica nas reduçôes. Estes são os casos de: Braco (2004); Santos e Baptista (2007); Levinton (2009). 
Argentina, Brasil, Paraguai e Uruguai. Sua particularidade é dada pelo conjunto de remanescentes materiais dos "Trinta Povos das Missóes" implantados na porção centro-sul da América do Sul".

A definição de um território específico para a instalação de um povoado reducional passava por critérios geográficos e estratégicos, Gutierrez (1987, p. 16) traz algumas prioridades dos jesuítas no agrupamento dos índios, aonde iam "ocupando as bacias fluviais e selecionando com cuidado os locais para assentamento, buscando pontos altos de clima benigno, fácil acesso e defesa, abastecidos de água e madeira”. Entre as trinta reduçóes, existiam modelos alternativos de planejamentos para integração do indígena, que conforme as potencialidades de cada local (recursos naturais, terras para cultivos e localizaçáo geográfica), somado ao esforço coletivo de cada missão, levou à definição das características produtivas e grau de desenvolvimento de cada povoado missioneiro.

Por conta disso, Barcelos (2000, p. 125) complementa que desde as primeiras instruçóes e recomendaçóes, percebe-se a importância destinada a determinadas características que o local futuramente deveria possuir.

A partir de revisóes bibliográficas e de materiais cartográficos, realizou-se uma análise a respeito de alguns fatores geográficos que poderiam ter influenciado na instalação estratégica da redução em destaque. Essa análise traz à luz novas possibilidades de investigação e refletem situaçóes dos campos geo-históricos e geopolíticos do período. Para tal, procuramos focar nosso raciocínio em três fatores de utilização do espaço (rede hidrográfica, estratégias territoriais e relaçóes sociais e comerciais).

Conforme nos mostra a Figura 2, entre todos os trinta povos, a redução São Francisco de Borja estava localizada na parte mais baixa da chamada mesopotâmia dos rios Uruguai e Paraná, estando apenas mais acima do leito que as reduçóes de Yapeyu e La Cruz. Outra análise que pode ser realizada refere-se à localizaçáo estratégica da fronteira missioneira São Borja-Brasil/Santo Tomé-Argentina, no âmbito do Rio Uruguai, estando as mesmas num trecho médio do rio que possibilitava a navegação ${ }^{5}$ (desde Iraí Norte do Estado do Rio Grande do Sul até a República Oriental do Uruguai). Esse fator pode justificar um maior controle por parte da Companhia de Jesus dos trechos navegáveis utilizados pelas reduçóes localizadas no alto Uruguai (o curso do rio vai no sentido alto/médio/baixo) e do trecho em direção ao estuário do Prata (trecho baixo do devido corpo d'água) ${ }^{6}$.

Em comparação com as outras reduçôes instaladas no setor oriental do Uruguai (áreas com maiores elevaçôes), a redução de São Francisco de Borja localizava-se numa área de planície que se aproximava ao nível do mar, fator que poderia facilitar o deslocamento terrestre e fluvial.

6 A rede hidrográfica que comporta a região apresenta uma grande diversidade de rios e arroios, com destaque para o rio Camaquá, estando próxima também da área de abrangência do rio Ibicuí. As pesquisadoras Heloisa Reichel e Ieda Gutfriend (1995) comentam que o rio Uruguai e seus afluentes foram utilizados pelos jesuítas e espanhóis para penetrarem nas terras do interior e aí estabelecerem suas reduçóes e seus povoados. 
FIGURA 2 | Mapa sobre a importância geopolítica da fronteira São Borja-Brasil/ Santo Tomé-Argentina

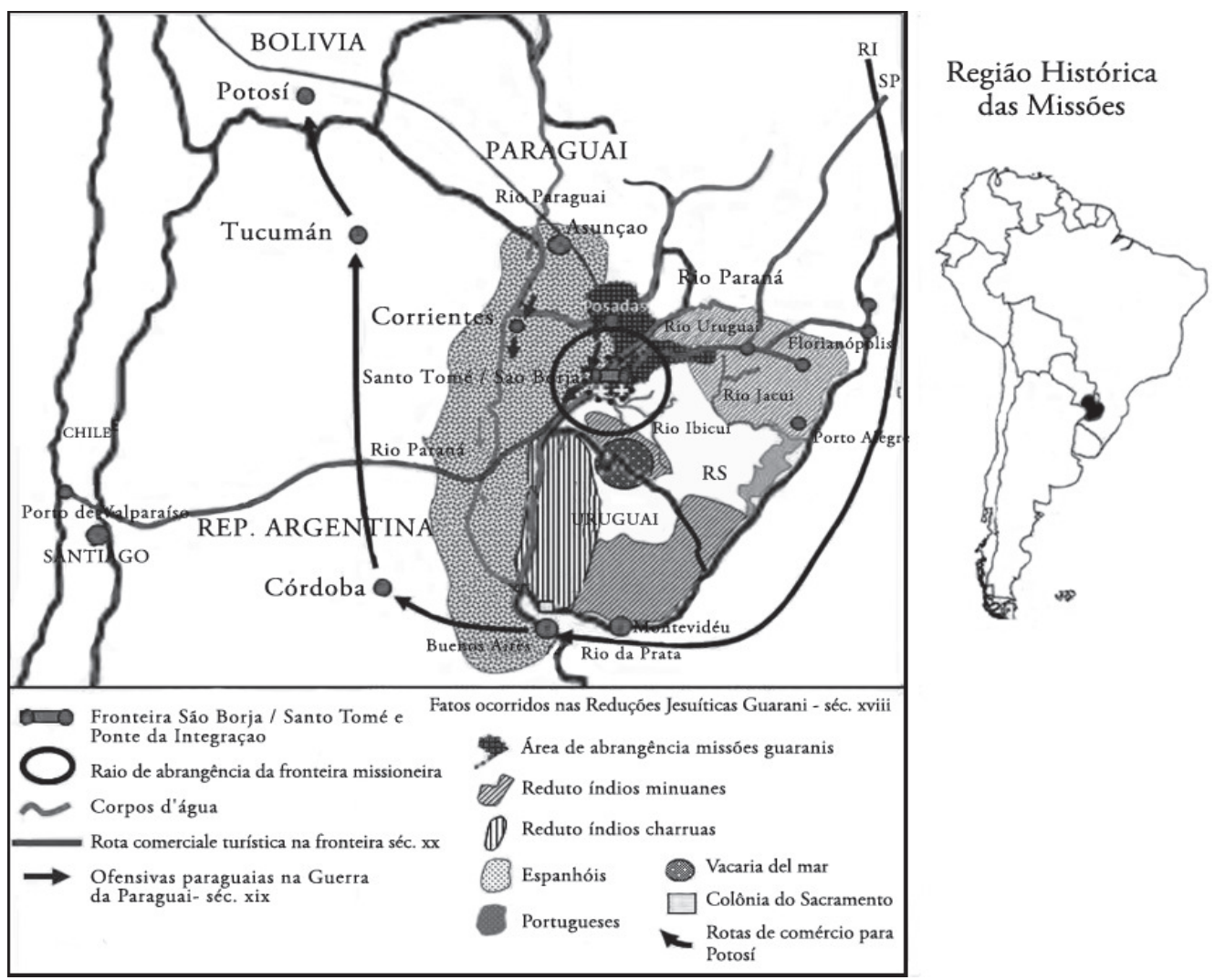

FONTE ELABORAÇão DE MURIEL PINTO

Em relação às características territoriais do espaço de formação da redução de São Francisco de Borja, concluímos que através da elaboração de material cartográfico, a fronteira em estudo localizava-se no centro do raio de abrangência da rota de comércio com Potosí . Essa relação comercial acabou instigando a fundação da Colônia do Sacramento (1680) por parte dos portugueses. A fundação dessa colônia foi um dos principais motivos do remanejamento de cinco reduçóes da margem ocidental para a oriental do Rio Uruguai, entre elas São Nicolau (1687), São Luis Gonzaga (1687), São Miguel Arcanjo (1687), São Borja (1690) e São Lourenço (1690) ${ }^{8}$. Segundo consta, "a redução de São Borja foi transladada para a Banda Oriental do Uruguai, devendo se conjugar com a de Santo Tomé, localizada na margem oposta, que inicialmente lhes prestaria apoio" (Neumann, 1996, p. 55). Esta observação fortalece a ideia de que São Borja foi fundada com a finalidade de dar sequência ao projeto político e administrativo que vinha sendo praticado pelos povos ocidentais (Yapeyu, La Cruz e Santo Thomé). E as evidências sáo ainda maiores quando observamos a

7 Regiáo mineira (hoje atual Bolívia).

8 As respectivas datas de fundação foram retiradas de Furlong (1962). 
movimentação étnica e cultural que envolveu o contingente destes povos, a partir de espaços compartilhados, no caso, as capelas e os passos do rio Uruguai'.

Outros fatores que nos parecem visíveis no que tange à estratégia territorial foi a preocupaçáo com a proteçáo aos campos de Vacaria do Mar e com a proximidade de outros grupos indígenas que habitavam a campanha Platina, como os guenoas, charruas e minuanos ${ }^{10}$. Nestes casos, torna-se evidente a importância defensiva do território. Maurer e Colvero (2009) salientam a importância combativa da redução borgista, visto que era considerada uma referência miliciana na margem oriental do rio Uruguai, por conta da sua importância fronteiriça e proximidade com os ditos grupos infiéis. No que diz respeito às relaçôes sociais da redução de São Francisco de Borja, mostrava-se diferenciada quanto às relaçóes administrativas e políticas da época. Novamente Maurer e Colvero (2009, p. 4332) esclarecem que "a redução de São Francisco de Borja foi um espaço de destaque entre os demais povos orientais do Uruguai. Situação registrada pelos próprios padres da Companhia de Jesus, quando estes tinham de desempenhar seu controle administrativo", fatores que também eram visualizados nas vestimentas e contatos orais "possuindo os índios mais bem vestidos e politizados das missóes" (Hilaire, 1821).

Essa politização da população nativa descrita pelo francês Saint-Hilaire, deixa transparecer através de uma reflexáo antropológica que o surgimento de diversos políticos samborjenses influentes no Brasil durante o século xx pode ter relação com a gênese populacional do século xviII. Com a decadência do projeto reducional, sobraram no espaço resquícios relacionados ao contexto social e econômico, o que possibilitou a materialização de símbolos culturais.

A região missioneira em geral possui seus bens patrimoniais relacionados ao próprio contexto reducional, cultura gaúcha e culturas europeias. Para Villegas (2008), "o Patrimônio Cultural da região das Missóes apresenta-se em primeira instância como o legado deixado pelos Guaranis e os Jesuítas nas reduçóes. Sáo um sem número de sítios arqueológicos espalhados por toda a região, quatro deles reconhecidos como patrimônio. Partindo de São Miguel Arcanjo, declarado Patrimônio Nacional em 1938 e da Humanidade em 1983, São João Batista, São Lourenço Mártir e São Nicolau declarados Patrimônio Nacional em 1970" (p. 8).

Villegas (2008) ainda esclarece que nas Missóes "se encontra um legado arquitetônico construído pelos descendentes de alemães, italianos e poloneses entre outros, constituído em sua maioria por conjuntos de edificaçóes e paisagens que lembram a influência europeia na arquitetura, gerado durante todo o período das imigraçóes no Rio Grande do Sul” (p. 8).

A regiāo histórica das reduçóes jesuíticas que pertence ao território brasileiro, até pouco tempo, era tratada pelo governo federal como um patrimônio espanhol. Foi

9 No raio que compreendeu as reduçóes de São Borja a Yapeyu existiram pelo menos 20 capelas e quatro passos de rios. Esses dados demonstram um interesse por parte dos jesuítas, bem como dos indígenas, em manter uma integraçáo e comunicação entre as reduçóes. Para saber mais sobre as capelas e passos e suas possíveis utilidades ver Snihur (2007) e Maurer (2011).

10 A fronteira missioneira estava situada em extensas áreas de pampas desabitadas, o que facilitava a penetração territorial por parte de outros grupos indígenas e dos próprios portugueses. Para saber mais sobre essa situação ver Garcia (2009) e Pereira (2012). 
apenas da década de 1920 que se realizou um estudo por parte do governo, onde o arquiteto brasileiro Lúcio Costa levantou informaçóes para decidir o que fazer com os chamados "Sete Povos das Missóes". Por circunstâncias específicas - os tratados entre Espanha e Portugal, os sítios ficaram "encalacrados" em território brasileiro. As expressóes utilizadas pelo arquiteto para definir a situação geográfica dos antigos povos missioneiros dão conta de que seus remanescentes eram considerados um patrimônio espanhol, e que nada tinham a ver com a cultura brasileira. $\mathrm{O}$ arquiteto continuou dizendo que as Missóes se constituíam em "um setor autônomo no conjunto dos monumentos coloniais brasileiros, por possuir remanescentes de uma cultura espanhola (Goelzer, 2008,p. 243). Nesse contexto, salienta-se que "o entendimento de que os remanescentes missioneiros eram herança estrangeira, desvinculada da história brasileira, perdurou durante muitas décadas. Moysés Vellinho registrou, em relação às Missóes: "só uma coisa nos ficou do passado morto: o papel de depositário de ruínas alheias" (Vellinho, 1970, p. 244).

Cabe comentar que a partir da década de 1930, o governo brasileiro começa dar uma maior atenção para a devida regiáo, com a atuação do Serviço de Patrimônio Histórico e Artístico Nacional (spHAN). Nesse sentido, as açóes de conservação, valorização e estudos se voltavam inteiramente para os sítios arqueológicos. Essa situação vem sendo alterada progressivamente, uma vez que as políticas de fomento atuais procuram contemplar todos os municípios missioneiros e não apenas os parques históricos. Diversos projetos estão se concretizando na regiáo através do Programa de Cooperação Instituto Andaluz de Patrimônio Histórico (IAPH)Sevilla/ Espanha- Instituto de Patrimônio Histórico e Artístico Nacional (IPHAN) Brasil. Conforme Nogueira e Burkhard (2008), "o acordo prevê estabelecimento de relaçóes de cooperação de caráter científico, tecnológico, formativo e cultural, em relação à documentação, conservação, formação e difusão do patrimônio histórico da Região das Missóes" (p. 29).

E nestas condiçóes, é de suma importância atentar-se para o caso de São Borja, pois uma interpretação acurada sobre tal localidade fará emergir situaçóes vinculadas ao período pré-hispânico e isso pode ser decisivo para uma releitura dos sítios históricos missioneiros.

\section{Uma análise da representação da cultura no espaço urbano local}

Para a interpretação da representação da cultura citadina, a área urbana de São Borja foi espacializada em duas zonas culturais: zona ribeirinha e zona central. No espaço delimitado para cada território, realizou-se, no primeiro momento, uma interpretação das práticas de ocupação, manipulação e exploração do espaço e suas interaçóes com as caracterizaçóes identitárias e culturais constituídas. Na sequência, realizou-se uma analise do processo cognitivo do espaço e suas categorias de simbolização, relacionados intimamente com a constituição das identidades sociais dos grupos envolvidos. Para tanto, foi produzido um mapa temático, que espacializou as principais tipologias patrimoniais inventariadas e suas respectivas áreas de abrangência, conforme as zonas culturais propostas. 


\section{Zona Ribeirinha}

Essa região da cidade é uma área periférica influenciada diretamente pelo Rio Uruguai. Seu processo de formação está relacionado ao desenvolvimento do comércio entre brasileiros e argentinos e pela cultura da pesca. Em relaçáo às comunidades inseridas nessa área de abrangência, foram identificados dois contingentes populacionais, os moradores do bairro do Passo e integrantes da colônia de pescadores Z-21. A partir do ano de 1994, com a construção da ponte da Integração São Borja/ Santo Tomé, houve o final do translado de embarcaçóes no antigo porto local, em virtude da mesma ter sido construída em outro espaço. Com a ponte, houve mudanças culturais e econômicas nessa região ribeirinha, visto que o fluxo era intenso em todos os dias da semana. Outro fator que gerou novas mudanças sociais e econômicas nesse local foi a reestruturação do Cais do Porto, área constituída por bares típicos e uma paisagem privilegiada do rio.

Com essa readequação do cais do porto, a zona ribeirinha tornou-se o principal atrativo turístico municipal. Entre os principais potenciais destaca-se a culinária típica (base de pescado), infraestrutura satisfatória, além dos bens naturais. Uma paisagem cultural pode ser conceituada como o reflexo das açóes do homem nas transformaçóes geográficas, sua visualização geralmente é reproduzida através da materializaçáo da cultura (símbolos), podendo ser representada como uma paisagem-marca (expressa uma civilização) e paisagem-matriz (dá sentido à cultura) (Cosgrove, 1998; Berque, 1998; Wagner \& Mikessel, 2003).

A interpretação dos bens patrimoniais e das narrativas emitidas nas musicalidades do espaço ribeirinho possibilitou a identificação de características culturais e discursivas pertencentes a uma identidade ribeirinha. Esta identidade sustenta-se através das relaçóes com a pesca. Para Claval (2001), "os lugares não tem somente uma forma e uma cor, uma racionalidade funcional e econômica. Eles estáo carregados de sentido para aqueles que os habitam ou que os frequentam" (p. 55) Em relação à delimitação da área cultural no contexto ribeirinho, definiu-se como centro de difusão cultural o cais do porto, pois o local destaca-se pela diversidade de manifestaçóes culturais. Entre os significados que os elementos simbolizados representam para a comunidade local, observou-se através da música ${ }^{11}$ e de imagens fotográficas, que o rio Uruguai salientase por possuir um número considerável de paisagens culturais.

A música Cantiga de rio e remo, de autoria de Apparício Silva Rillo e Manoel Bicca, expressa bem algumas representaçóes do Rio Uruguai:

Olha o dourado que bateu no espinhel;

Traz a canoa, que no fundo não da pé

Leva a canoa quando eu saio noite a fora

Pescando estrela do Uruguai e do Ibicui;

Ele remanso, é cachoeira, é lua cheia;

Ela é piava, ela dourado é surubi,

Tirou das águas para o solo um lambari;

É o pão na mesa para a fome de quem pesca ${ }^{12}$.

11 Interpretação realizada através da análise discursiva de composições musicais do grupo artístico "Os Angüeras".

12 Letra denominada cantiga de rio e remo. Autoria de "Os Angüeras". 
FIgURA 3 | Composição musical do festival da Barranca do rio Uruguai

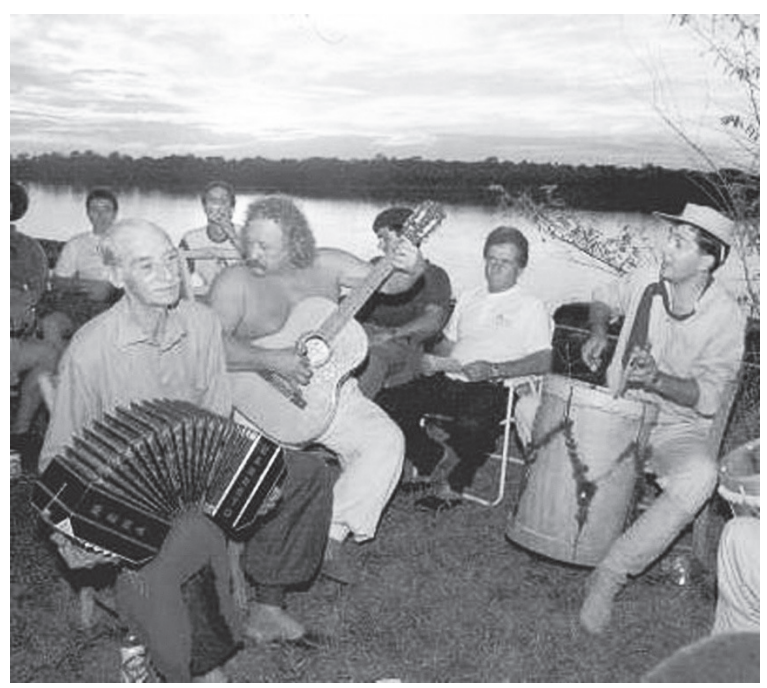

FONTE GRUPO OS ANGUERAS

O devido corpo d'água é exaltado pelos discursos analisados como um elemento espacial transmissor de mística, sentimentos, emoçóes, marcador de diferença (exaltação de São Borja), de diversão (banhos, esportes náuticos), fonte de alimento, local de realização de festividades musicais (ver Figura 3). A representação do cais do porto, tanto pelo discurso da administração pública ${ }^{13}$ como pelas narrativas da população14, demonstrou ser um espaço peculiar no território samborjense. A Secretaria de Turismo de Sáo Borja salienta que "o Cais do Porto e o Rio Uruguai oferecem excelentes alternativas de lazer, diversão e esportes, em um ambiente único e característico da cidade" (ver Figura 7). Em relação à gastronomia local, a prefeitura municipal reconhece a peculiaridade da culinária ribeirinha, ou seja, procura publicitar turisticamente o produto típico local: "em São Borja existem ótimos hotéis e restaurantes, com gastronomia típica de alta qualidade (não deixe de provar o peixe frito nos bares da Cais)". Já o discurso local apresentou "vozes" de pertencimento comunitário onde alguns atores se identificaram como sendo "passeanos", denominação popular para quem é morador do bairro do passo ${ }^{15}$.

\section{Zona Central}

A área cultural da zona central surge espacialmente no ano de 1690, com a instalação da redução de São Francisco de Borja. Com a formação desse núcleo administrativo, surgiu o primeiro aglomerado populacional e urbano local. O século XVIII, nos seus primeiros anos, representou o ápice do desenvolvimento urbano e social da redução borjista, que teve destaque na arquitetura através do suporte técnico do arquiteto italiano Joseph Brasanelli. Para Colvero e Maurer (2009), a

13 Os discursos emitidos pela prefeitura de São Borja foram analisados através do site da instituição. Ver: www.saoborja.rs.gov.br

14 As mensagens expostas pela população foram analisadas através de entrevista oral.

15 Entrevista com senhora Adiles Calazans Pinto. 
participaçáo do irmáo Brasanelli foi de grande importância para a redução, pois deixou um legado barroco no local, onde "é de sua autoria, a imagem esculpida do padroeiro da antiga reduçáo: Padre Francisco de Prada e Gandia; além da edificação do antigo templo" (p. 435).

A partir da década 1750, Sáo Borja sofreu os impactos da decadência das reduçóes jesuíticas guarani, concretizando a decadência do projeto num sentido geral $^{16}$. O pós-missóes marcou a troca da posse territorial das áreas pertencentes à Coroa Espanhola para o domínio português. Esse processo de colonizaçáo portuguesa acaba contribuindo para o desenvolvimento das grandes propriedades rurais samborjense através da divisão de terras das sesmarias. O desenvolvimento da pecuária acabou constituindo alguns tipos sociais como o latifundiário, estancieiro, figura do gaúcho. Esses atores constituíram relaçóes de poder na economia, no contexto social e na cultura, o que possibilitou a construção de manifestaçóes culturais no centro da cidade, onde residem até hoje. $\mathrm{O}$ tipo arquitetônico eclético dos imóveis centrais é um exemplo prático dessa influência estancieira. Após uma leitura dos bens culturais desse espaço central e da interpretação dos corpos discursivos gerados pelas musicalidades e documentos primários, observa-se que essa zona apresenta uma diversidade de tipologias patrimoniais e um hibridismo entre as identidades. Essa miscigenaçáo identitária vincula-se principalmente com a representação simbólica da cultura missioneira, essencialismo da história dos presidentes, cultura gaúcha, tradiçóes urbanas e memória futebolística.

No que diz respeito ao levantamento das paisagens culturais do centro da cidade, foram selecionados espaços simbolizados que demonstraram possuir "características de linhas ou avenidas de disseminação e penetração cultural" (Wagner \& Mikesell, 2003). Foram delimitadas como avenidas culturais: o entorno da praça Xv de Novembro, os bairros Maria do Carmo e Cemitério (encontra-se o Jazigo de João Goulart e Leonel Brizola ${ }^{17}$ ), uma vez que estes locais destacaram-se por possuírem uma grande quantidade de tipologias patrimoniais e de discursos relacionados a representaçóes culturais da cidade. A área do entorno da praça XV de Novembro ${ }^{18}$ apresenta paisagens com traços fixos sobre as figuras dos ex-presidentes. A localização estratégica (áreas com fluxo intenso de pessoas) e quantidade expressiva dessas manifestaçóes culturais (monumentos ${ }^{19} \mathrm{e}$ instituiçôes culturais) demonstram uma

16 Atribuí-se a decadência do projeto reducional na região disposta à assinatura do Tratado de Madri (1750). Na prática significou a (re)definição de fronteiras entre as coroas ibéricas na América Meridional. A oficialização do tratado foi repudiada por algumas lideranças indígenas, o que a historiografia costumou chamar de Guerra Guaranitica (1754-1756). Tanto o episódio do tratado quanto o da rebeliâo indígena são temas recorrentes em vários trabalhos, nesse caso salientamos: Quarleri (2009), Neumann (2010).

17 Personalidade política destacada no cenário brasileiro.

18 O cemitério Jardim da Paz também apresentou símbolos ligados à identidade trabalhista como os túmulos de João Goulart e do líder pedetista Leonel Brizola. Todos os anos na data de morte de Getúlio Vargas são realizadas celebraçôes no cemitério.

19 Cita-se o: Mausoléu Getúlio Vargas (Praça xv), estátuas (presidentes) em frente à prefeitura e espalhadas pela praça. A construção modernista da Prefeitura (leva o nome de Palácio João Goulart). Ainda verificam-se dois imóveis com arquitetura eclética que pertenceram aos dois presidentes (foram utilizadas como sedes de museus que representam a história dos devidos líderes). 
ideia voltada para a exaltação desses líderes políticos, o que expóe ações em prol da construção de uma identidade de projeto, conforme descreve (Castells, 1999): utilização da cultura com viés político.

Nesta direção, observa-se a busca construtiva de uma identidade local, que envolve uma relação entre ideologia política (trabalhista) e cultura. Do ponto de vista discursivo, vem sendo utilizado pelas últimas administraçóes públicas o slogan "Terra dos Presidentes". Esse ideário voltado para a exaltação desses líderes já era utilizado na década de 70 (ver Figura 4), onde a imagem de Getúlio Vargas localizava-se estrategicamente no centro da praça Xv. Hoje se encontra nesse local um Mausoléu com os restos mortais do ex-presidente.

Cabe comentar, que também foram inventariados resquícios da cultura missioneira (séculos XVII e XVIII), como o sítio arqueológico da antiga redução borjista ${ }^{20} \mathrm{e}$ elementos culturais pertencentes à igreja católica (pia batismal e estatuárias missioneiras $\left.{ }^{21}\right)$. A representação das missôes ${ }^{22}$ pela igreja católica é também percebida no nome da Igreja Matriz "São Francisco de Borja" e na frente da mesma, através de imagens da cruz de Lorena (principal símbolo missioneiro). A identidade missioneira possui uma relação de influência na constituição das outras formas identitárias locais, e consequentemente sobre o Patrimônio Histórico-Cultural, como exemplo na construçáo da identidade gaúcha (utilização da erva-mate; cultura da criação de gado; carne assada; instrumentalidade; utilizaçáo de artefatos de defesa e próprio discurso do tipo gaúcho missioneiro). Esse tipo identitário caracteriza-se no local pela exaltação da diferença com outras municipalidades das Missôes, visto que exalta o fato de ser um dos "Sete Povos das Missóes".

\section{FIgura 4 | Praça Xv Novembro na década de 1970 (exaltação da figura de Getúlio Vargas)}

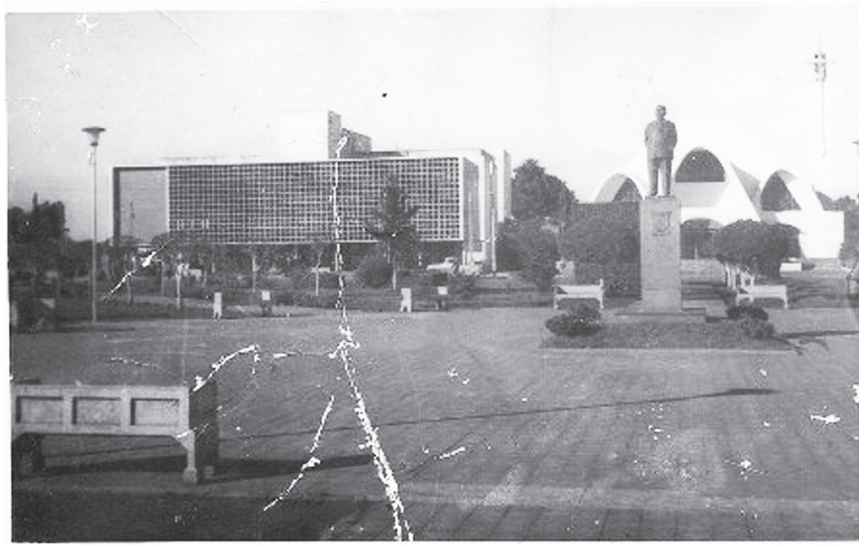

FONTE SENHORA ADILES CALAZANS PINTO

20 Dos integrantes dos Sete Povos das Missóes, São Borja é o único que não possui estudos arqueológicos no seu sítio missioneiro. Conforme a planta urbana municipal, o sítio arqueológico da Redução de São Francisco de Borja localiza-se no entorno da Praça xv de novembro, exatamente onde foi a sede de instalação do povoado missioneiro.

21 Entre elas constam no acervo duas estatuárias de São Francisco de Borja, considerado padroeiro do município.

22 Ainda inventariaram-se bens culturais missioneiros no acesso da cidade (Estátua de São Francisco de Borja), cruz de Lorena, monumento do Tricentenário da fundação da Redução, Museus Missioneiro e um retábulo missioneiro na Igreja do bairro do passo. 
O bairro Maria Carmo foi definido como outra subárea cultural da zona central. Essa regiáo da cidade apresenta paisagens culturais vinculadas a tradiçóes populares, como a da procissão de São João Batista, lenda urbana de Maria do Carmo, a memória futebolística (Internacional de São Borja) e cultura gaúcha nativista (Grupo de Artes "Os Angüeras"). A denominação do bairro vincula-se à principal lenda urbana samborjense. Conforme Rillo (2004), Maria do Carmo era uma mulher de vida "airada", pessoa que levava apoio material e espiritual à gente de São Borja, no século xix, sendo assassinada por volta de 1890 . Outra tradição popular que se celebra nessa área é a procissão de São João Batista. Essa manifestação possui um caráter religioso e popular junino, ocorrendo desde 1879 todos os dias 23 de junho $^{23}$. O cortejo religioso com a imagem de "São Joãozinho Batista" (como é chamada pelo discurso popular) é realizado num trajeto pela cidade até a fonte missioneira de São João ${ }^{24}$, onde é banhada num ritual de cantos e rezas.

\section{As identidades "flutuantes" da cidade Histórica de Sáo Borja: a relaçáo material da cultura/ poder}

Como se pode observar, desde a última década do século XviI, São Borja possui uma trajetória histórica "marcada" por acontecimentos relevantes no cenário sulamericano. Fatores esses que proporcionaram a construçáo de identidades ${ }^{25}$ e a materialização de um grande número de bens culturais no espaço local ${ }^{26}$. Segundo Woodward (2000), o processo de construção de uma identidade pode ser simbólico (dá sentido tanto as práticas como as relaçôes sociais) como social (busca uma relação de diferença com outras culturas). Esse contexto de formação identitária busca nos antecedentes históricos elementos para a constituição de símbolos e discursos, nos quais acabam dando essência aos elementos culturais. A busca pela diferença é uma forma de impor uma identidade, através de criaçóes sociais e culturais. Conforme os sistemas de significação e representação cultural se multiplicam, surgem novas identidades, isto é, elas são cambiantes (Hall, 2003; Silva, 2000).

23 Em uma documentação curiosa de 1883, a Câmara Municipal da Villa de São Francisco Borja solicita ao Presidente da Província de São Pedro do Rio Grande do Sul (atualmente Estado do Rio Grande do Sul), um "repasse" financeiro para arcar com os gastos da procissão. O argumento é a que procissão atraia "curiosos" de várias "paragens" do Prata e portanto era "merecedora" de tal empenho. ahrgs, Fundo Fazenda.

24 Nas primeiras décadas, o santo era banhado numa lagoa que se localizava próximo ao centro da cidade. Regiáo essa que hoje comporta uma Praça, que leva o nome popular de "Praça da Lagoa".

25 Nacionalmente, o local é conhecido por "Terra dos Presidentes", "Primeiro dos Sete Povos das Missōes" e "berço do trabalhismo". Em outras épocas já foi lembrada como a "Capital da Produçấo" e "Capital do Linho". Por conta das referências históricas e das identidades aclaradas, São Borja recebeu o reconhecimento de "Cidade Histórica" (Decreto Estadual de 11/10/1994).

26 Conforme o estudo "Levantamento do Patrimônio Cultural e Natural da Região das Missôes" realizado pelo iphan; IAPH (Instituto Andaluz de Patrimônio Histórico - Sevilha, Espanha) e URI (Universidade Regional Integrada do Alto Uruguai e das Missóes) o município de São Borja foi considerado um dos três municípios polos da Região das Missôes no que se refere à quantidade de recursos de interesse patrimonial. 
Em relação ao local, "constata-se diversos tipos de identidades, como: a missioneira, pampiana, trabalhista, ribeirinha e fronteiriça”" (M. Pinto, 2010). Tipos identitários que são representados e reconhecidos no contexto do Patrimônio Histórico-Cultural. Esses bens contribuem para a criação de novas simbologias e discursos, o que está proporcionando a construção de identidades cambiantes. O processo de formaçáo de uma identidade se inicia através de uma forma identitária primária que vem a se tornar móvel (processo de "troca" cultural) ao longo dos tempos (Castells, 1999).

A análise da cultura através das açóes de poder é uma das formas modernas pela qual a Geografia Cultural vem movendo-se teoricamente. Segundo Cosgrove (1998), a intervenção do poder na cultura torna-se evidente no processo de reprodução de elementos culturais, ou seja, na construçáo de identidades, discursos, elementos materializados, símbolos, entre outros. Frequentemente, estamos convivendo com subculturas dentro de uma cultura dominante, "cada uma destas subculturas encontra alguma expressão na paisagem, mesmo se apenas uma paisagem de fantasia" (p. 105). Sendo assim, "as culturas subdominantes podem ser divididas não apenas nos termos já indicados, mas também historicamente, como residuais (que sobraram do passado), emergentes (que antecipam o futuro) e excluídas (que são ativa ou passivamente suprimidas) como as culturas do crime, drogas ou grupos religiosos marginais" (p. 105). Este raciocínio de Cosgrove foi colocado em prática através de um estudo de caso na cidade histórica de São Borja, Brasil.

Neste momento, podem-se identificar quais eram os tipos de cultura existentes e seus respectivos graus de influência no cenário exposto. Neste contexto, também foram analisados como os símbolos culturais foram/são arquitetados e utilizados no espaço. Para tanto, a partir da análise do Patrimônio Histórico-Cultural, da análise das representaçóes culturais e da historiografia regional, foi possível perceber as manifestações culturais gaúchas ou pampianas, como dominantes no espaço. Suas influências sociais são reproduzidas constantemente no local, visto que a regiáo há muitas décadas é influenciada economicamente e socialmente pelos costumes relacionados à lida campeira e à figura do gaúcho.

Esta geografia proporcionou, desde o período das reduçóes jesuíticas (séculos XVII e XVIII), interesses estratégicos por esse espaço territorial. Conforme Haesbaert (1988) o espaço da campanha no Brasil estruturou politicamente seu território a partir do "estabelecimento da linha fronteiriça (só definida no inicio do séc. XIX); a construção do espaço latifundiário (a partir da doação de sesmarias), forma de apropriação dominante" (p. 78). As características do relevo e da vegetação regional foram fundamentais para a criaçáo de rebanhos de gado nas chamadas vacarias Del Mar (ver Figura 5). Com a consolidação do processo político administrativo do território, houve o surgimento de um tipo social proprietário das terras rurais e encarregado pela criação do gado, chamado de gaúcho. Portanto, esta atividade pecuarista foi responsável pela construção da figura do gaúcho primeiramente na Argentina e Uruguai, e posteriormente no Brasil, o que elevou através de relaçóes de poder a proliferação dos costumes, saberes e tradiçóes culturais relacionadas ao tipo social em questão. 
Segundo Oliven (1990) "dois aspectos são comuns àqueles que, a partir de perspectivas diversas, cultuam as tradiçóes gaúchas: a presença do campo, mais especificamente da regiáo da Campanha, localizada no sudoeste do Rio Grande do Sul, na fronteira com Argentina e Uruguai; e a figura do gaúcho, homem livre e errante, que vagueia soberano em seu cavalo, tendo como interlocutor privilegiado a natureza das vastas planícies dessa área pastoril” (p. 1). Em relação à reprodução ou construção dos recursos culturais gaúchos, cabe comentar que essa identidade já faz parte do senso comum local, uma vez que suas representaçóes são constantes na lida campeira, nos CтG's (Centros culturais tradicionalistas Gaúchos), no cotidiano (indumentária; musicalidade; dança; gastronomia e festividades). Essa construção identitária apresenta o gaúcho como uma figura mítica relacionada ao bioma pampa, às estâncias (grandes propriedades rurais), à lida campeira, ao cavalo, churrasco (carne assada), mate (bebida típica) e à pecuária (criação de gado) (ver Figura 6). A relação de poder que existe nessa identidade está relacionada às influências sociais e culturais que os grandes proprietários rurais (estancieiros) exercem através de seu poder econômico e territorial no local.

\section{FIgURA 5 | Localização de Sáo Borja na regiáo de influencia do bioma pampa}

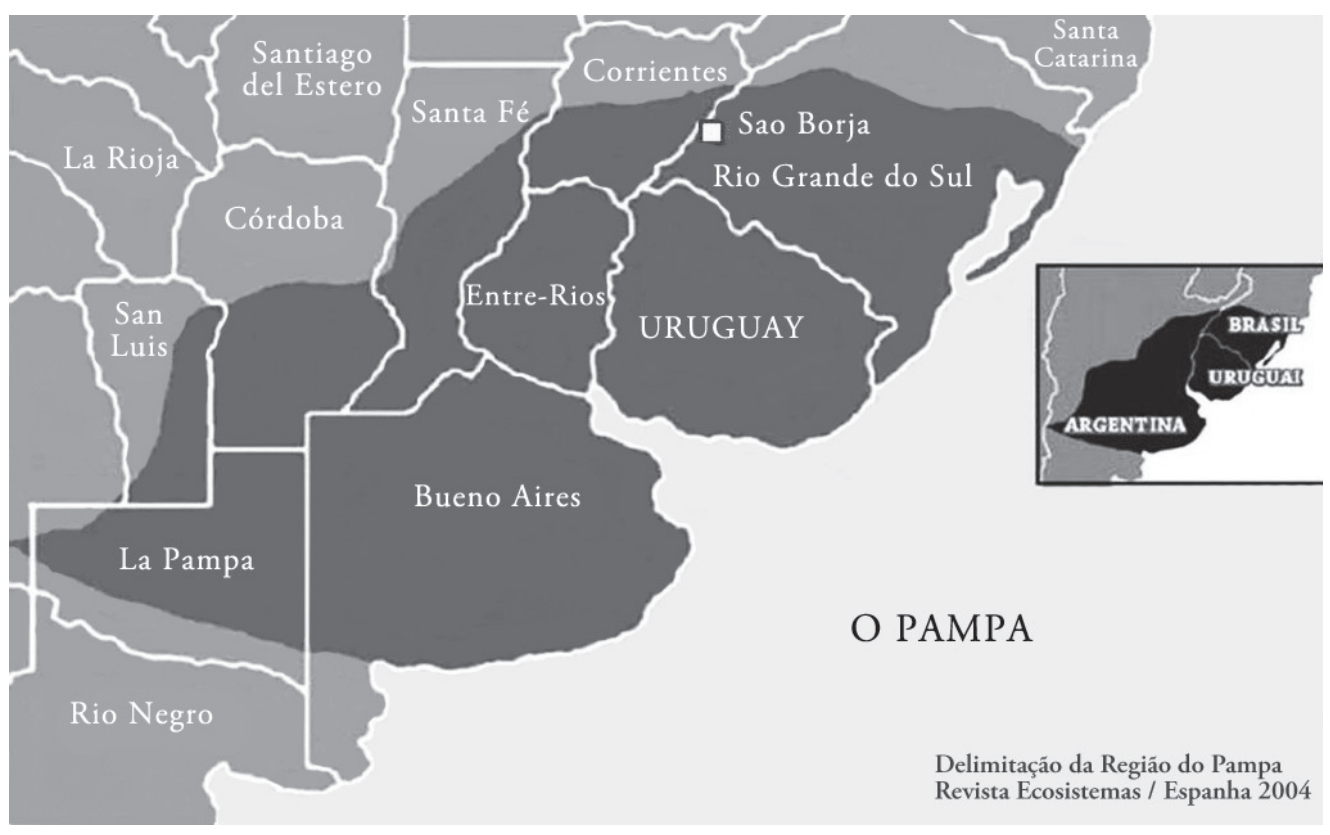

FONTE REVISTA ECOSISTEMAS, ADAPTADO POR MURIEL PINTO 
QUADro 1 | Tipos identitários de Sáo Borja

\begin{tabular}{|c|c|c|}
\hline TIPO DE IDENTIDADE & $\begin{array}{l}\text { CULTURA MATERIALIZADA } \\
\text { (REPRODUÇÃO) }\end{array}$ & PRINCIPAIS POLÍTICAS \\
\hline \multirow{8}{*}{$\begin{array}{l}\text { Identidade Gaúcha } \\
\text { Tipo: Cultura dominante }\end{array}$} & Museu Ergológico de Estância & $\begin{array}{l}\text { Difusão da cultura -Grupo artístico os } \\
\text { Angüeras }\end{array}$ \\
\hline & $\mathrm{CTG}^{\prime} \mathrm{s}$ & $\begin{array}{l}\text { Projetos realizados pelas entidades } \\
\text { gauchas }\end{array}$ \\
\hline & Semana Farroupilha & $\begin{array}{l}\text { Projeto de potencialização do evento } \\
\text { (município) }\end{array}$ \\
\hline & Endumentária & \multirow{5}{*}{$\begin{array}{l}\text { Desenvolvidas por açôes de mercado } \\
\text { e pelas entidades tradicionalistas e } \\
\text { sociedade civil }\end{array}$} \\
\hline & Musicalidade e festivais & \\
\hline & Dança & \\
\hline & Lida campeira & \\
\hline & Gastronômia & \\
\hline \multirow{7}{*}{$\begin{array}{l}\text { Identidade Trabalhista } \\
\text { Tipo: Cultura residual/ } \\
\text { emergente }\end{array}$} & Museu Getúlio Vargas & \multirow{7}{*}{$\begin{array}{l}\text { Verifica-se açôes voltadas para usos } \\
\text { turísticos, políticos e identitários }\end{array}$} \\
\hline & Museu João Goulart & \\
\hline & Mausoléu de Getúlio Vargas & \\
\hline & Jazigo de Jango e Brizola & \\
\hline & Estatuárias de Jango e Getúlio & \\
\hline & Palácio João Goulart & \\
\hline & Partidos Políticos locais & \\
\hline \multirow{8}{*}{$\begin{array}{l}\text { Identidade Missioneira } \\
\text { Tipo: Cultura residual/ } \\
\text { emergente }\end{array}$} & Museu Missioneiro & \multirow{8}{*}{$\begin{array}{l}\text { Os "usos" da cultura reproduzida por } \\
\text { essa identidade estão centralizados entre } \\
\text { Igreja, município e mercado }\end{array}$} \\
\hline & Monumento do Tricentenário & \\
\hline & Igreja Matriz & \\
\hline & Fonte missioneira de São João & \\
\hline & Folderes turísticos & \\
\hline & Procissão de São João Batista & \\
\hline & Brasão do município & \\
\hline & São Francisco de Borja (acesso) & \\
\hline \multirow{7}{*}{$\begin{array}{l}\text { Identidade Ribeirinha } \\
\text { Tipo: Cultura excluída/ } \\
\text { emergente }\end{array}$} & Colônia de pescadores Z 21 & \multirow{7}{*}{ Principalmente por açóes de mercado } \\
\hline & Bairro do Passo & \\
\hline & Cais do Porto & \\
\hline & Gastronômia típica & \\
\hline & Rio Uruguai & \\
\hline & Festa do Peixe & \\
\hline & Festas populares & \\
\hline
\end{tabular}

FONTE ELABORAÇÃo DE MURIEL PINTO 
FIGURA 6 | Desfile da semana Farroupilha em São Borja

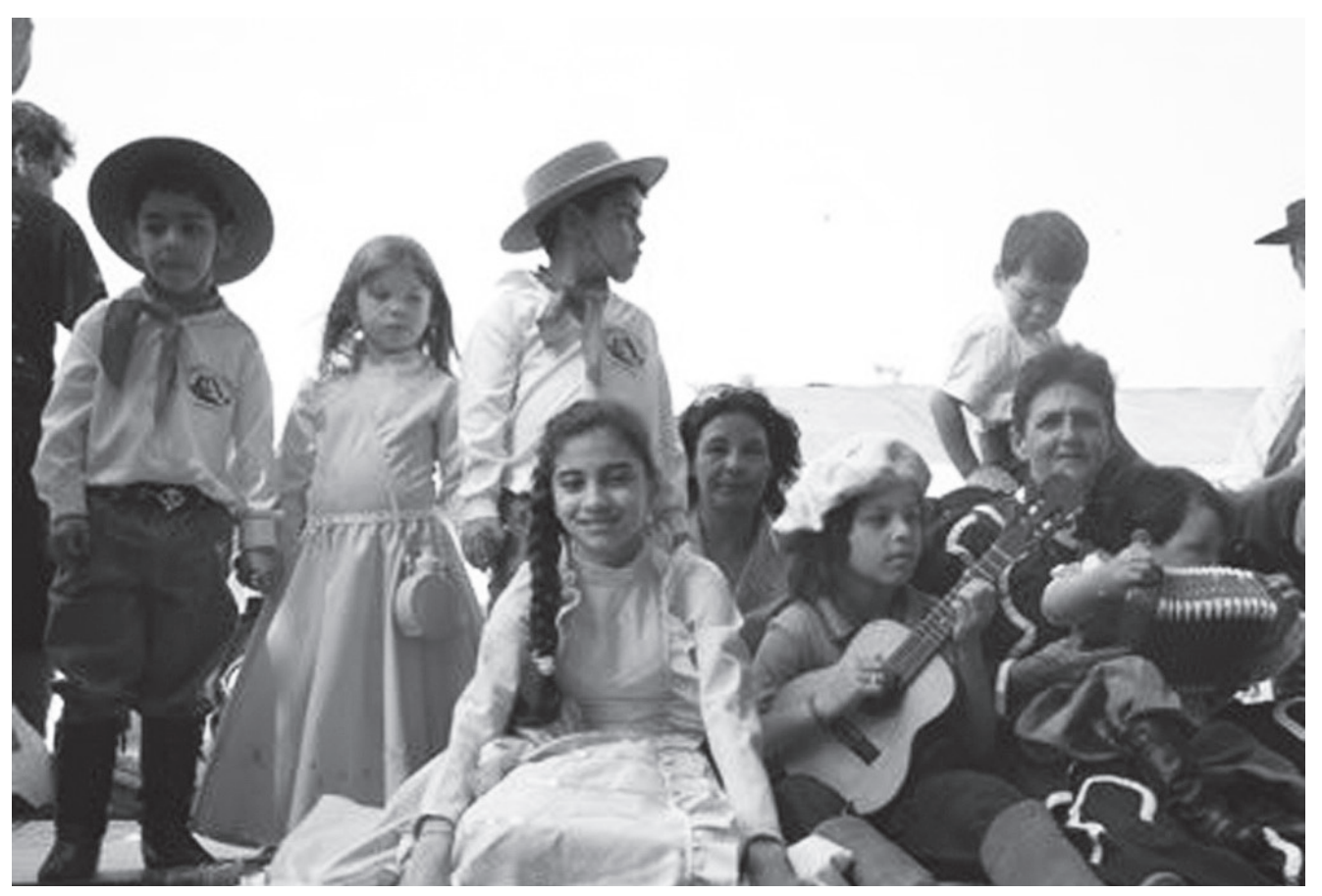

FONTE FLASHSB. WWW.FLASHSB.COM.BR

As demais identidades que estão presentes no local, como a ribeirinha, foram agrupadas no estudo ao grupo das culturas alternativas. Os recursos patrimoniais que representam a cultura trabalhista e missioneira, por suas características históricas, foram inseridos no subgrupo das culturas residuais, denominadas por Cosgrove (1998) como "aquelas que sobram do passado". Ao mesmo tempo seus elementos identificam-se com o subgrupo da cultura emergente, "caracterizada por antecipar o futuro". Já a cultura ribeirinha foi denominada como excluída pelo baixo índice de políticas culturais executadas até o momento (ver Quadro 1).

Através da análise das tipologias patrimoniais representadas pela identidade trabalhista, pelo discurso público-comunitário e pelas políticas público-privadas de exaltação dos líderes políticos, foi possível constatar que os símbolos culturais que exaltam as figuras dos ex-presidentes brasileiros Getúlio Vargas e João Goulart, podem ser interpretados através de três formas de utilização: uso político, uso turístico e uso cultural-educacional (ver Figura 7).

A partir destas três formas interpretativas da utilização da cultura, observa-se que o poder público e o mercado dividem forças no que se refere à construção desses símbolos. Em relação à utilização dos recursos culturais por um viés político, verifica-se que as siglas partidárias trabalhistas (РDT е Ртв) procuram relembrar o passado dos ex-presidentes como instrumentos de mobilizaçáo eleitoral, legitimação da ideologia trabalhista e de mitificação desses líderes. Nesse caso, as referências são remanejadas de forma estratégica visando estabelecer uma identificação das massas, o que Allan Bloom (1989) chama de "culturas criadas". 
FIGURA 7 | Monumentos em homenagem aos ex-presidentes Getúlio Vargas e João Goulart

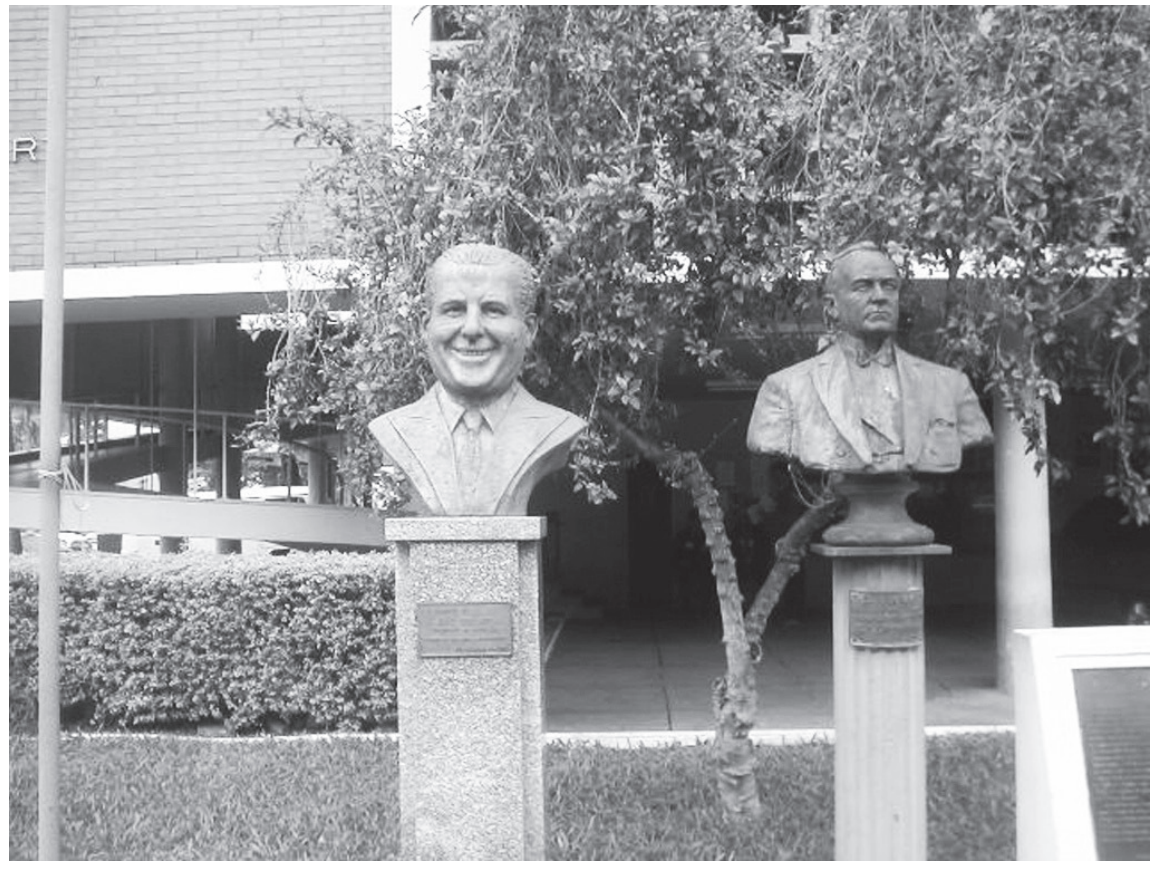

FONTE MURIEL PINTO

Figura 8 | Símbolos missioneiros expostos na igreja Matriz Sáo Francisco de Borja

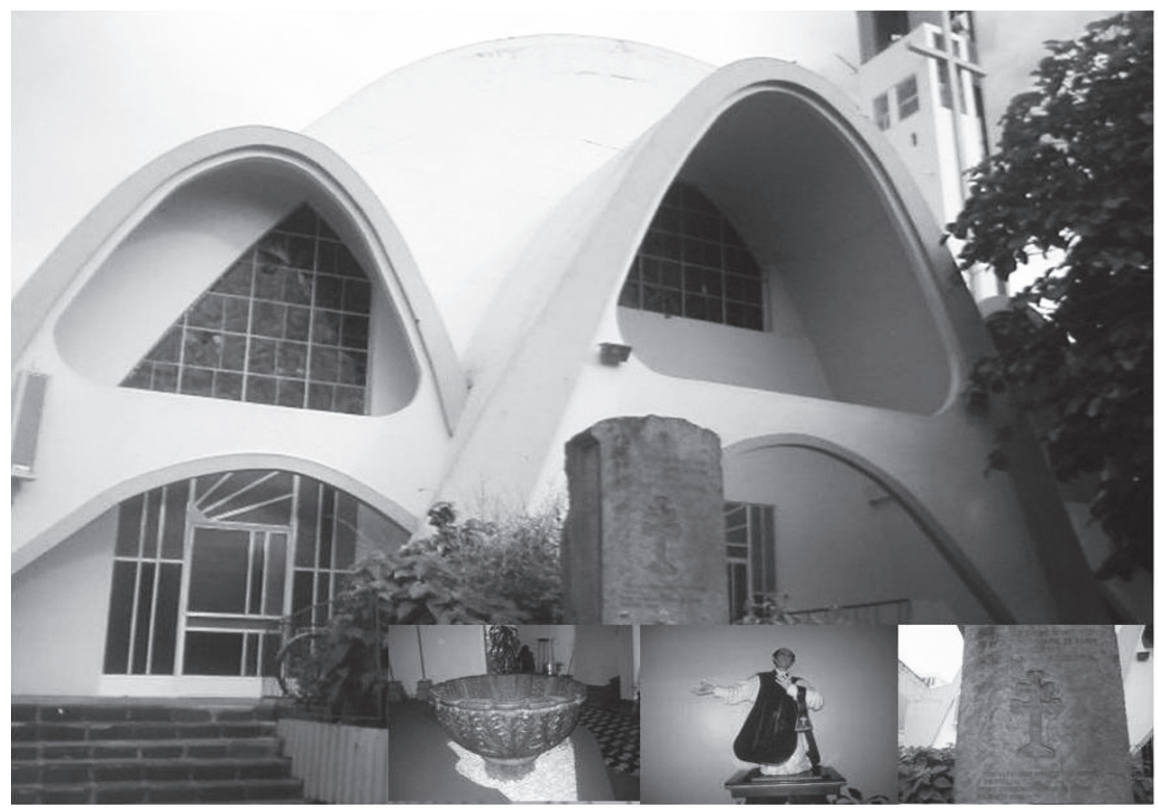

FONTE MURIEL PINTO 
No que diz respeito à cultura missioneira, dois períodos foram importantes para a materialização dessa identidade. O primeiro foi o ano de 1982, data comemorativa aos 300 anos de fundação da redução de São Francisco de Borja, embora a mesma nunca tenha sido comprovada por fontes primárias. Em 2006, com a entrada de São Borja no projeto turístico Rota Missóes, surge o segundo momento. Essas duas iniciativas criaram e materializaram elementos relacionados às Missóes Jesuíticas Guarani. Neste caso, levantaram-se quatro formas de poder que intervém na devida cultura: Igreja Católica (posse de estátuas), mercado (rotas turísticas; criação de produtos missioneiros); município (posse do museu missioneiro e planejador de políticas culturais e turísticas), e sociedade civil (colecionadores de bens materiais e elaboração de artesanato típico) (ver Figura 8).

Em relação aos usos turísticos e culturais dos símbolos trabalhistas, missioneiros, gaúchos e ribeirinhos, nota-se que desde 2005, o município vem planejando estrategicamente seus recursos culturais e patrimoniais de forma a potencializá-los para o turismo. Entre as iniciativas cita-se: reestruturação de museus; projetos de restauro (casa de Getúlio Vargas e Jango); eventos culturais; açóes de educação patrimonial; localização de sítio Histórico (2007) e institucionalizaçáo da cultura e a própria publicidade da cultura.

\section{Consideraçóes finais}

O grande desafio dessa construção interdisciplinar foi integrar conceitos de identidade, cultura, patrimônio sem os vícios rotineiros que cada área do conhecimento carrega. Neste sentido, procuramos articular a abordagem de maneira que possibilitasse uma interpretação crítica e abrangente sobre as paisagens culturais do atual município de São Borja. O resultado provou como a cultura é representada no espaço e como as formas de poder influenciam para a construção de elementos essencializados. Este raciocínio permitiu realizar uma interpretação inicial das paisagens culturais de Sáo Borja, que poderá servir como material para futuras pesquisas na área, inclusive no planejamento e execução do Projeto Itinerário Cultural das Missóes Jesuíticas Guarani, proposto pela Unesco, governo brasileiro e argentino.

Foi possível registrar elementos culturais que simbolizam um número maior de momentos históricos, como: período reducional; Guerra do Paraguai; período republicano (materialização dos presidentes da república); relaçóes de fronteira e cultura pampiana. No caso in foco, seu Patrimônio Histórico apresenta tipologias e recursos culturais diferenciados em relação à parte noroeste da região das Missóes. Não só por sua trajetória histórica de reconhecida representatividade no âmbito nacional, mas também pela sua identificação regional tanto com a Campanha Gaúcha, identidade missioneira e identidade fronteiriça, além da pequena imigraçáo, fatores estes que contribuirão para uma maior diversificação das características tipológicas dos recursos de interesse patrimonial.

Sobressaíram-se também discursos de pertencimento ao local, onde sujeitos da comunidade exaltaram a diferença do lugar perante outras localidades missioneiras e do próprio Estado do Rio Grande do Sul, Brasil. Partindo da análise dos "usos" da cultura e de patrimônios materiais tangíveis, demonstrou-se que a 
identidade trabalhista é a única a utilizar os bens patrimoniais como instrumento político. Já em relação à utilização turística dos bens culturais, os elementos estão sendo construídos de forma a planejar atrativos turísticos "marcados" pela alteridade, estereotipia e naturalização. Uma análise sobre as paisagens constatou que a cultura missioneira está representada em todo o território local, elementos estes que "misturam-se" com outros tipos identitários, o que permite verificar "trocas" ou "miscigenações" dos símbolos e discursos missioneiros entre as identidades gaúcha, trabalhista e fronteiriça. Na zona ribeirinha notou-se através da análise discursiva, uma relação de pertencimento maior por parte da população comparada com a zona central, visto que essa área cultural apresentou um pequeno numero de elementos culturais relacionados a outras identidades, ou seja, uma pequena hibridização identitária.

Por fim, diante dos resultados alcançados, a grande contribuição do estudo foi a exposição de uma visão integradora sobre determinadas situaçóes e objetos que estão relacionados a uma evoluçáo consciente e contemporânea de um município de fronteira. Eis o motivo pelo qual resolvemos estabelecer esse diálogo geo-histórico.

\section{Referências bibliográficas}

Barcelos, A. (2000) Espaço e arqueologia nas missóes jesuiticas: o caso de São João Batista. Porto Alegre: EDIPUCRS.

Berque, A. (1998). Paisagem-marca, paisagem-matriz: elementos da problemática para uma geografia cultural. In R. L. Corrêa \& Z. Rosendhal, Paisagem, tempo e cultura. Rio de Janeiro: EdUERJ - Editora da Universidade do Estado do Rio de Janeiro.

Bloom, A. (1989). O declinio da cultura ocidental (3a ed.). São Paulo: Best Seller.

Braco, D. (2004). Los errores Charrúa y Guenoa-Minuán. In Jahrbuch für Geschichte Lateinamerikas [Anuario de Historia de América Latina], 41, pp. 117-136. Acesso em http://dialnet.unirioja.es/servlet/articulo?codigo=2202187

Canclini, N. G. (2011) Culturas híbridas: estratégias para entrar e sair da modernidade. Sáo Paulo: Editora da Universidade de São Paulo.

Castells, M. (1999). O poder da identidade. Tradução K. Brandini Gerhardt. São Paulo: Paz e Terra.

Claval, P. (2001). A geografia cultural. Tradução de L. Fugazzola Pimenta e M. de Castro Afeche Pimenta ( $2^{\mathrm{a}}$ ed.). Florianópolis: Editora da Universidade Federal de Santa Catarina (UFSC).

Colvero, R. \& Maurer, R. (2009). Um caso mal resolvido: os Sete Povos das Missôes e o julgamento de 1759. Revista Digital Estudios Históricos, 2. Acesso em http://dialnet. unirioja.es/servlet/articulo?codigo $=3051414$

Colvero, R. \& Maurer, R. (2010). São Borja e seu Patrimônio "quase esquecido: o caso das Missōes Jesuíticas na Terra dos Presidentes. In: IV Congresso Internacional de História. Maringá: Universidade Estadual de Maringá. Disponível em http://www.pph.uem.br/ cih/anais/trabalhos/313.pdf 
Cosgrove, D. (1998). A geografia está em toda parte: Cultura e simbolismo nas paisagens urbanas. In R. L. Corrêa \& Z. Rosendhal (Orgs.), Paisagem, tempo e cultura (pp. $92-$ 123). Rio de Janeiro: EdUERJ - Editora da Universidade do Estado do Rio de Janeiro.

Furlong, G. (1962). Misiones y sus Pueblos de Guaranies. Buenos Aires: Teorema.

Garcia, E. F. (2007). As diversas formas de ser indio: políticas indigenas e politicas indegenistas no extremo sul da América Portuguesa. Tese de doutoramento, Universidade Federal Fluminense (UFF), Niterói.

Goelzer, A. L. (2008) Patrimônio Histórico e Artístico Nacional no Rio Grande do Sul no século XX: atribuiçôes de valores e critérios de intervençâo. Tese de Doutorado orientada por Sandra Jatahy Pesavento. Porto Alegre: Programa de Pós-Graduação em Planejamento e Uso de Recursos Renováveis (PPGPUR)/Universidade Federal do Rio Grande do Sul (UFRGs).

Gruzinski, S. (2007). El pensamiento mestizo: Cultura amerindia y civilización del Renacimiento. Buenos Aires: Paidós.

Gutiérrez, R. (1987). As missóes Jesuiticas dos Guaranis. Rio de Janeiro: Serviço de Patrimônio Histórico e Artístico Nacional (sPHAN).

Haesbaert, R. (1988). Latifúndio e identidade regional. Porto Alegre: Mercado Aberto.

Hall, S. (2003). A identidade cultural na pós-modernidade. Tradução de T. T. da Silva, G. Lopes de Louro ( $7^{\text {a }}$ ed.). Rio de Janeiro: DP\&A Editora.

Instituto do Patrimônio Histórico e Artístico Nacional (IPHAN), Instituto Andaluz de Patrimônio Histórico (IAPH), Universidad Regional Integrada (URI). (2008). Levantamento do patrimônio cultural e natural da Regiáo das Missóes. Santo Ângelo, Brasil. Acesso em http://www.urisan.tche.br/ -iphan

Levinton, N. (2009). Guaraníes y charrúas: una frontera exclusivista-inclusivista. Revista de História Regional 14(1), 49-75. Acesso em http://www.revistas2.uepg.br/index.php/ rhr/article/viewFile/2282/1769

Maurer, R. (2011). Do um que não é sete: o caso da antiga redução de San Francisco de Borja e a dinâmica da diferença. Dissertação de Mestrado, Programa de Pós-Graduação em História (PPGH), Universidade de Passo Fundo (UPF).

Neto, J. B. (2007). A luta como herança: Recepção Estética e Turismo nas Ruinas da Redução de São Miguel Arcanjo. Tese de Doutorado orientada por Lisbeth Ruth Rebollo Gonçalves, Universidade de Sáo Paulo.

Neumann, E. (1996). O trabalho guarani missioneiro no Rio da Prata colonial, 1640-1750. Porto Alegre: Martins Livreiro.

Neumann, E. (2010). Episódios de rebeliāo na fronteira: a Guerra Guaranítica (1752-1756). In E. Neumann \& L. A. Grijó, O continente em armas: uma história da guerra no sul do Brasil (pp. 47-75). Rio de Janeiro: Apicuri.

Nogueira, C. R. D. (2007). Turismo, o reencontro e a redescoberta da Regiāo das Missóes. Tese de Doutorado orientada por Francisco Capuano Scarlato, Universidade de São Paulo.

Nogueira, C. R. D. \& Burkhard, D. (2008). Políticas públicas de turismo para o desenvolvimento local/regional. Revista Eletrônica de Turismo Cultura, 2(2), 1-32. Acesso em http:// www.eca.usp. br/turismocultural/Retc04_arquivos/Carmen_Missoes.pdf

Oliven, R. G. (1990). Em busca do tempo perdido: o movimento tradicionalista gaúcho. [Em línea]. Revista Brasileira de Ciências Sociais, ANPOCS (Associação Nacional de PósGraduação e Pesquisa em Ciências Sociais), 15, 1-24. Acesso em http://www.anpocs. org.br/portal/publicacoes/rbcs_00_15/rbcs15_03.htm 
Pereira, C. C. (2012). "Y hoy están en paz": relaçôes sócio-politicas entre os indios 'infiéis' da banda oriental e guaranis missioneiros no século XVIII (1730-1801). Dissertação de Mestrado, Programa de Pós-Graduação em História (PPGH), Universidade Federal do Rio Grande do Sul (ufrgs), Porto Alegre.

Pinto, A. C. (2010). Entrevista concedida a Muriel Pinto. Relaçôes sociais, culturais e históricas do Bairro do Passo de São Borja. São Borja, 20 de abril, 2010.

Pinto, M. (2010). A cidade como fenômeno cultural: os impactos territoriais das transformaçóes do patrimônio cultural e da identidade na cidade histórica de São Borja-RS. In XVI Encontro de Geógrafos Brasileiros. [Em línea]. Porto Alegre: Universidade Federal do Rio Grande do Sul (Ufrgs) / Associação dos Geógrafos Brasileiros (AGB). Acesso em http://www.agb.org.br/xvieng/anais/edp. php

Pinto, M. \& Nogueira, C. R. D. (2009). Gestão integrada do território com patrimônio histórico: Uma ferramenta de planejamento turístico para a área de fronteira São Borja (Estado do Rio Grande do Sul, Brasil) / Santo Tomé (Corrientes, Argentina). [CD-Rom]. In XI Simpósio Nacional de Geografia Urbana. Brasília: Universidade de Brasília, 2009.

Quarleri, L. (2009). Rebelión y guerra en las fronteras del Plata: guaranies, jesuitas e imperios coloniales. Buenos Aires: Fondo de Cultura Económica.

Reichel, H. J. \& Gutfreind, I. (1995). Fronteiras e guerras no Prata. São Paulo: Atual.

Rillo, A. S. (2004). Populário São-borjense. São Borja: Nova Prova.

Rillo, A. S. \& Bicca, J. Cantiga de rio e remo. Intérpretes: Rillo e Bicca. In Rillo; Bicca. Irmãos de Arte. São Borja: Nativismo Editora e Produtora Cultural. 1 disco sonoro, lado A, faixa 13.

Saint-Hilaire, A. (1997). Viagem ao Rio Grande do Sul. Porto Alegre: Martins Livreiro.

Santos, M. C. dos. (1993). Aspectos de la resistencia guarani: los proyectos de integración en el Virreinato del Río de La Plata (1768-1805). Tesis doctoral. Departamento de Antropología Americana, Facultad de Geografia e Historia, Universidad Complutense de Madrid, Madrid.

Santos, M. C. dos \& Baptista, J. (2007). Reduçôes jesuíticas e povoados de índios: controvérsias sobre a população indígena (séc. XVII - XVIII). História Unisinos, 11(2), 240-251. Acesso em http://repositorio.furg.br:8080/handle/1/873

Silva, T. T. da. (2000). A produçáo social da identidade e da diferença. In T. T. da Silva, Identidade e diferença: a perspectiva dos estudos culturais. Petrópolis,RJ: Vozes.

Snihur, E. (2007). El universo misionero guarani. Buenos Aires: Sudamérica Joven Ensayo.

unesco Brasil, Argentina. (2009). Anteprojeto de itinerários culturais do Mercosul. Salvador, Brasil: UNESCO.

Villegas, M. (2008). Evolução e diagnóstico dos recursos de interesse patrimonial da Região das Missōes. Levantamento do patrimônio cultural e natural da Região das Missóes. Santo Ângelo: Universidade Regional Integrada do Alto Uruguai e das Missóes (URI). Acesso em http:// www.urisan.tche.br/ -iphan/upload/downloads/file669.pdf

Wagner, P. L. \& Mikesell, M. W. (2003). Os temas da Geografia Cultural. In R. L. Corrêa \& Z. Rosendahl, Introdução à Geografia Cultural. Rio de Janeiro: Bertrand, Brasil.

Woodward, K. (2000). Identidade e diferença: uma introdução teórica e conceitual. In T. T. da Silva, Identidade e diferença: a perspectiva dos estudos culturais. Petrópolis, RJ: Vozes. 


\section{Fontes}

Archivo General de la Nación Argentina (Agna), Buenos Aires.

Arquivo Histórico do Rio Grande do Sul (Ahrgs), Porto Alegre.

FLASHSB. Fotografia do desfile da semana Farroupilha. 1 fotografia, colorida. São Borja: 2010. Acesso em http://www.flashsb.com.br/?setor=66\&A=2378.

Freitas, J. M. de. Fotografia do festival musical Barranca do Rio Uruguai. 1 fotografia; colorida. Blog de Juarez Machado de Freitas. Acesso em 21 de outubro de 2012, de: http:// juarezmachadodefarias.blogspot.com/2009/01/o-que-o-festival-da-barranca.html

Movimento Tradicionalista Gaúcho (MTG). Símbolo do MTG. Acesso em http://www.mtg.org. br/site/pag_simbologia.php

Prefeitura Municipal de São Borja. (2010). Informaçóes culturais e turísticas. São Borja, Brasil. Acesso em http://saoborja.rs.gov.br 